\title{
RESEARCH
}

\section{High-sensitivity cardiac troponin on presentation to rule out myocardial infarction: a stepped-wedge cluster randomised controlled trial}

Atul Anand, M.D. Ph.D,1* Kuan Ken Lee, M.D.,1* Andrew R. Chapman, M.D. Ph.D, $1^{*}$ Amy V. Ferry, Ph.D.,1 Phil D. Adamson, M.D. Ph.D.,1,2 Fiona E. Strachan, Ph.D.,1 Colin Berry, M.D.,3 Iain Findlay, M.D.,4 Anne Cruikshank, M.D.,5 Alan Reid, M.Sc.,5 Paul O. Collinson, M.D.,6 Fred S. Apple, Ph.D.,7 David A. McAllister, M.D.,8 Donogh Maguire, M.D. Ph.D.,9 Keith A.A. Fox, M.B.Ch.B.,1 David E. Newby, M.D. Ph.D.,1 Chris Tuck, B.Sc.,10 Ronald Harkess, B.Sc.,10 Catriona Keerie, M.Sc.,10 Christopher J. Weir, Ph.D.,10 Richard A. Parker, M.Sc.,10 Alasdair Gray, M.D.,11,12 Anoop S.V. Shah, M.D. Ph.D.,1,12* Nicholas L. Mills, M.D. Ph.D.1,12* on behalf of the HiSTORIC Investigators $\dagger$

\footnotetext{
4 Department of Cardiology, Royal Alexandra Hospital, Paisley, UK. George's University of London, London, UK.

8 Institute of Health and Wellbeing, University of Glasgow, Glasgow, UK.

9 Emergency Medicine Department, Glasgow Royal Infirmary, Glasgow, UK.

12 Usher Institute, University of Edinburgh, Edinburgh, UK.

*Contributed equally

Listed in the Supplement

\section{Corresponding Author:}

Professor Nicholas L Mills

$\mathrm{BHF} /$ University Centre for Cardiovascular Science

The University of Edinburgh

Edinburgh EH16 4SA

United Kingdom

Telephone: 00441312426515

Fax: 00441312426379

E-mail: nick.mills@ed.ac.uk
}

1 BHF Centre for Cardiovascular Science, University of Edinburgh, Edinburgh, UK.

2 Christchurch Heart Institute, University of Otago, Christchurch, New Zealand.

3 Institute of Cardiovascular and Medical Sciences, University of Glasgow, Glasgow, UK.

5 Department of Biochemistry, Queen Elizabeth University Hospital, Glasgow, UK.

6 Departments of Clinical Blood Sciences and Cardiology, St George's, University Hospitals NHS Trust and St

7 Department of Laboratory Medicine and Pathology, University of Minnesota, Minneapolis, MN, USA.

${ }_{10}$ Edinburgh Clinical Trials Unit, Usher Institute, University of Edinburgh, Edinburgh, UK.

11 Emergency Medicine Research Group Edinburgh, Royal Infirmary of Edinburgh, Edinburgh, UK.

$\begin{array}{ll}\text { Abstract } & 352 \\ \text { Word count } & 2,824\end{array}$

Tables \& Figures

5

NOTE: This preprint reports new research that has not been certified by peer review and should not be used to guide clinical practice. 
medRxiv preprint doi: https://doi.org/10.1101/2020.09.06.20189308; this version posted September 8, 2020. The copyright holder for this preprint (which was not certified by peer review) is the author/funder, who has granted medRxiv a license to display the preprint in

It is made available under a CC-BY-NC-ND 4.0 International license .

\section{Abstract}

Objectives: High-sensitivity cardiac troponin assays enable myocardial infarction to be ruled out earlier, but the efficacy and safety of this approach is uncertain. We investigated whether an early-rule out pathway is safe and effective for the management of patients with suspected acute coronary syndrome.

Design: A stepped-wedge cluster randomised controlled trial.

Setting: Seven acute care hospitals in Scotland.

Participants: 31,492 consecutive patients with suspected acute coronary syndrome between December 2014 to December 2016.

Intervention: Sites were randomised to implement an early rule-out pathway where myocardial infarction was ruled out if high-sensitivity cardiac troponin I concentrations were $<5 \mathrm{ng} / \mathrm{L}$ at presentation. During a prior validation phase, myocardial infarction was ruled out where troponin concentrations were $<99$ th centile at 6-12 hours after symptom onset.

Main outcome measures: The co-primary outcome was length of stay (efficacy), and myocardial infarction or cardiac death after discharge at 30 days (safety). Patients were followed for 1 year to evaluate the safety outcome and other secondary outcomes.

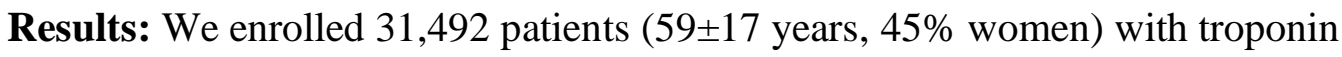
concentrations $<99_{\text {th }}$ centile at presentation. The length of stay was reduced from $10.1 \pm 4.1$ to $6.8 \pm 3.9$ hours (adjusted geometric mean ratio $0.78,95 \%$ confidence interval $[\mathrm{CI}] 0.73$ to $0.83, \mathrm{P}<0.001)$ following implementation, and the proportion of patients discharged increased from $50 \%$ to $71 \%$ (adjusted odds ratio [aOR] $1.59,95 \%$ CI 1.45 to 1.75 ). Non-inferiority was not demonstrated for the 30-day safety outcome (upper limit of one-sided 95\% CI for 
medRxiv preprint doi: https://doi.org/10.1101/2020.09.06.20189308; this version posted September 8, 2020. The copyright holder for this preprint (which was not certified by peer review) is the author/funder, who has granted medRxiv a license to display the preprint in It is made available under a CC-BY-NC-ND 4.0 International license.

adjusted risk difference $0.70 \%$, non-inferiority margin $0.50 \%, \mathrm{P}=0.068)$, but the observed differences favoured the early rule-out pathway $(0.4 \%[57 / 14,700]$ versus $0.3 \%[56 / 16,792])$. At 1 year, the safety outcome occurred in $2.7 \%(396 / 14,700)$ and $1.8 \%(307 / 16,792)$ of patients before and after implementation (aOR 1.02, 95\% CI 0.74 to $1.40, \mathrm{P}=0.894$ ), and there were no differences in hospital reattendance or all-cause mortality.

Conclusions: Implementation of an early rule-out pathway for myocardial infarction reduced length of stay and hospital admission. Whilst non-inferiority for the safety outcome was not demonstrated at 30 days, there was no increase in cardiac events at 1 year. Adoption of this pathway will have major benefits for patients and healthcare providers.

Trial registration: ClinicalTrials.gov number, NCT03005158 
medRxiv preprint doi: https://doi.org/10.1101/2020.09.06.20189308; this version posted September 8, 2020. The copyright holder for this preprint (which was not certified by peer review) is the author/funder, who has granted medRxiv a license to display the preprint in

It is made available under a CC-BY-NC-ND 4.0 International license .

\section{Introduction}

There are over 20 million presentations with suspected acute coronary syndrome each year in the US alone, 1 accounting for up to a tenth of hospital visits and 40 percent of unscheduled admissions.2 Given that most patients do not have myocardial infarction, 3 the adoption of effective and safe pathways to rule out myocardial infarction in the Emergency Department and avoid hospital admission would have a major impact on patient care and healthcare provision.

Cardiac troponin testing is an integral component of the assessment of patients with suspected acute coronary syndrome, with guidelines recommending serial testing at presentation and 6-12 hours later to coincide with the peak in troponin concentration. 4 The development of high-sensitivity cardiac troponin assays with enhanced precision at very low concentrations permits quantification well below the 99 th centile diagnostic threshold for myocardial infarction.5 This advance has led to innovative pathways to rule out myocardial infarction more rapidly, either at presentation or within 3 hours.6-13 However, these studies were observational, and there are few examples where the pathway guided patient care.14,15 The majority were modest in size, or enrolled selected low-risk patients, and therefore the true efficacy and safety of introducing these pathways into clinical practice remains uncertain.

Our aim was to determine the efficacy and safety of implementing an accelerated pathway where high-sensitivity cardiac troponin testing is used to rule out myocardial infarction at presentation in consecutive patients with suspected acute coronary syndrome. 
medRxiv preprint doi: https://doi.org/10.1101/2020.09.06.20189308; this version posted September 8, 2020. The copyright holder for this preprint (which was not certified by peer review) is the author/funder, who has granted medRxiv a license to display the preprint in

It is made available under a CC-BY-NC-ND 4.0 International license .

\section{Methods}

\section{Trial Design and Oversight}

High-Sensitivity cardiac Troponin $O$ n presentation to Rule out myocardial InfarCtion (HiSTORIC) is a stepped-wedge cluster randomised controlled trial enrolling consecutive patients with suspected acute coronary syndrome across seven acute hospitals in Scotland. In this trial, the hospital site was the unit of randomisation. The trial was approved by the Scotland A Research Ethics Committee and the conduct of the trial was periodically reviewed by an independent trial steering committee. All data were collected from the patient record and national registries, deidentified and linked in a data repository (DataLochтм, Edinburgh, UK) within secure NHS safe havens.16

\section{Trial Population}

Sites were eligible if they had the capacity to introduce the early rule-out pathway and returned data to the national registry. All patients in the Emergency Department were identified by the attending clinician using an electronic form integrated into the care pathway at the time troponin was requested. Patients were eligible for inclusion if they presented with suspected acute coronary syndrome and had a troponin concentration within the normal reference range at presentation. Patients were excluded if they presented with an out-ofhospital cardiac arrest or ST-segment elevation myocardial infarction, had been admitted previously during the trial or were not resident in Scotland. 
medRxiv preprint doi: https://doi.org/10.1101/2020.09.06.20189308; this version posted September 8, 2020. The copyright holder for this preprint (which was not certified by peer review) is the author/funder, who has granted medRxiv a license to display the preprint in

It is made available under a CC-BY-NC-ND 4.0 International license .

\section{Randomisation}

The trial was conducted across three phases (Figure 1a). During a validation phase of 6-9 months, troponin testing was performed at presentation and repeated 6-12 hours after the onset of symptoms if indicated (standard care). In accordance with guidelines at the time of enrolment,4,17 myocardial infarction was ruled out where troponin concentrations were less than the $99_{\text {th }}$ centile at presentation if symptom onset was $>6$ hours from presentation, or following serial testing 6-12 hours from symptom onset. Sites were paired based on the expected number of patients and randomised to implement the early rule-out pathway (intervention) in one of three steps during a 6-month randomisation phase. Finally, all sites completed an implementation phase of 6-9 months calendar matched to the validation phase where care was guided by the early rule-out pathway.

\section{Intervention}

The High-Sensitivity Troponin in the Evaluation of patients with suspected Acute Coronary Syndrome (High-STEACS) early rule-out pathway (Figure 1 b) has been described previously.18,19 Myocardial infarction is ruled out in patients with troponin concentrations $<5$ $\mathrm{ng} / \mathrm{L}$ at presentation, unless they present within 2 hours of symptom onset where testing is repeated 3 hours from presentation. Patients with troponin concentrations $\geq 5 \mathrm{ng} / \mathrm{L}$ at presentation are retested 3 hours after presentation, and myocardial infarction is ruled out if concentrations are unchanged (delta $<3 \mathrm{ng} / \mathrm{L})$ and remain below the $99_{\text {th }}$ centile. To support implementation, we provided educational material and presentations at each site, a webapp (www.highsteacs.com), and formal training for clinical staff in the Emergency Department (eMethods in Supplement). Throughout the trial, all sites used the Abbott ARCHITECTSTAT high-sensitive troponin I assay to guide clinical decisions. This assay has an inter-assay 
medRxiv preprint doi: https://doi.org/10.1101/2020.09.06.20189308; this version posted September 8, 2020. The copyright holder for this preprint (which was not certified by peer review) is the author/funder, who has granted medRxiv a license to display the preprint in It is made available under a CC-BY-NC-ND 4.0 International license .

coefficient of variation of less than $10 \%$ at $4.7 \mathrm{ng} / \mathrm{L}, 8,20$ and a 99 th centile of $16 \mathrm{ng} / \mathrm{L}$ in women and $34 \mathrm{ng} / \mathrm{L}$ in men.21

\section{Trial Outcomes}

We used regional and national registries to follow-up the trial population.16,22-23 Sequential hypothesis testing evaluated two co-primary outcomes in an a-priori defined hierarchical order: the primary efficacy outcome followed by the primary safety outcome. The primary efficacy outcome was length of stay, defined as the length of time from presentation to the Emergency Department until discharge from hospital. The safety outcome was myocardial infarction (type 1, type 4 b or type $4 \mathrm{c}$ ) or cardiac death after discharge which was evaluated at 30 days (primary) and 1 year (secondary) following presentation. These events were adjudicated by a panel blind to the study phase. All subsequent presentations where any troponin concentration was $>99_{\text {th }}$ centile were reviewed and adjudicated as described previously (eMethods in Supplement).16,24,25

The secondary efficacy outcome measure was the proportion of patients discharged from the Emergency Department. Other safety outcome measures included myocardial infarction, cardiac death, cardiovascular death, all-cause death, unplanned coronary revascularisation and reattendances for any reason after discharge at 1 year. Adherence was evaluated for three prespecified components of the early rule-out pathway (eMethods in Supplement).

\section{Statistical Analysis}

All outcomes were analysed using a linear mixed-effects regression model, adjusting for hospital site (random effect), season, time of presentation since start of study, and an 
medRxiv preprint doi: https://doi.org/10.1101/2020.09.06.20189308; this version posted September 8, 2020. The copyright holder for this preprint (which was not certified by peer review) is the author/funder, who has granted medRxiv a license to display the preprint in

It is made available under a CC-BY-NC-ND 4.0 International license .

indicator variable for whether the early rule-out pathway had been implemented. Length of stay was log-transformed prior to analysis and results expressed as a geometric mean ratio. If the analysis of the primary efficacy outcome was significant at the 5\% level, then we planned to perform a non-inferiority analysis of the primary safety outcome reporting a risk difference (intervention-standard care) and one-sided 95\% confidence interval. If the upper limit of the one-sided $95 \%$ confidence interval was below a $0.5 \%$ non-inferiority margin, then noninferiority was established, and if it was below $0 \%$ then superiority was established. A sensitivity analysis compared outcomes during the calendar matched period in the validation and implementation phases using the same regression model as for the primary analysis, but without adjustment for time or season. A number of other sensitivity analyses were performed (eMethods in Supplement).

\section{Patient and public involvement}

A patient review panel was consulted throughout the trial programme and provided input on the educational advice provided to clinicians following introduction of the new pathway. Qualitative research capturing the views and experiences of patients treated within these pathways will follow in a separate publication. Patients were not involved in the conception or design of the trial. 
medRxiv preprint doi: https://doi.org/10.1101/2020.09.06.20189308; this version posted September 8, 2020. The copyright holder for this preprint (which was not certified by peer review) is the author/funder, who has granted medRxiv a license to display the preprint in It is made available under a CC-BY-NC-ND 4.0 International license .

\section{Results}

\section{Trial Sites and Population}

Seven acute hospitals were eligible and all participated (Table S1). Between December, 2014, and December, 2016, a total of 31,492 consecutive patients with suspected acute coronary syndrome $(59 \pm 17$ years, $45 \%$ women) met the inclusion criteria (Figure S1). There were $14,700(47 \%)$ and $16,792(53 \%)$ patients assessed before and after implementation of the early rule-out pathway, respectively. Clinical characteristics were similar before and after implementation (Table 1) and across all three phases of the trial (Table S1). The trial concluded in December, 2017 with 1 year of follow up available in 31,428 (99.8\%) patients.

\section{Primary and Secondary Efficacy Outcomes}

Length of stay was reduced from 10.1 \pm 4.1 to $6.8 \pm 3.9$ hours (adjusted geometric mean ratio $0.78,95 \%$ confidence interval $[\mathrm{CI}] 0.73$ to $0.83, \mathrm{P}<0.001$ ) following implementation of the early rule-out pathway (Table 2 , Figure 2). The proportion of patients discharged from the Emergency Department without hospital admission increased from 50\% to 71\% (adjusted odds ratio $1.59,95 \%$ CI 1.45 to 1.75 ). Adherence to all three prespecified components of the early rule-out pathway was observed in 11,600/16,792 (69\%) of patients.

\section{Primary and Secondary Safety Outcomes}

Before and after implementation of the early rule-out pathway, the primary safety outcome of myocardial infarction or cardiac death following discharge at 30 days occurred in $57 / 14,700$ $(0.4 \%)$ and 56/16,792 (0.3\%) patients respectively (Table 2$)$ with an adjusted odds ratio of 1.97 (95\% CI 0.95 to $4.08, \mathrm{P}=0.068)$. Comparing the rate of the primary safety outcome after implementation to the rate before, the upper limit of our one-sided $95 \%$ confidence interval for the adjusted risk difference was $0.70 \%$, exceeding our prespecified non-inferiority margin 
medRxiv preprint doi: https://doi.org/10.1101/2020.09.06.20189308; this version posted September 8, 2020. The copyright holder for this preprint (which was not certified by peer review) is the author/funder, who has granted medRxiv a license to display the preprint in It is made available under a CC-BY-NC-ND 4.0 International license .

of $0.50 \%$. The event rate at 30 days was lower than anticipated, and our regression model and prespecified sensitivity analyses gave divergent results (Table S3). However, there were 703 (2.2\%) patients with myocardial infarction or cardiac death following discharge at 1 year (Figure 3). Before and after implementation, the secondary safety outcome measure occurred in 396/14,700 (2.7\%) and 307/16,792 (1.8\%) patients, respectively (adjusted odds ratio 1.02, 95\% CI 0.74 to $1.40, \mathrm{P}=0.894)$. Furthermore, the rate of all other safety outcome measures at 1 year did not differ before and after implementation (Table 2).

\section{Sensitivity Analysis in Calendar Matched Validation and Implementation Phases}

In total 18,241 (58\%) patients attended during the calendar-matched phases with 8,673 (48\%) and 9,568 (52\%) evaluated during the validation and implementation phase respectively. Length of stay was reduced from $10.6 \pm 4.1$ to $6.8 \pm 4.0$ hours (adjusted geometric mean ratio $0.65,95 \%$ CI 0.62 to 0.68 ) before and after implementation of the early rule-out pathway. The primary safety outcome occurred in 43/8,673 (0.5\%) and 23/9,568 (0.2\%) patients at 30 days, with an adjusted odds ratio of 0.48 ( $95 \%$ CI 0.29 to $0.80, \mathrm{P}=0.005)$. The upper limit of our one-sided $95 \%$ confidence interval for the adjusted risk difference was $-0.13 \%$, which was below our superiority margin of $0 \%$. The secondary safety outcome occured in 251/8,673 (2.9\%) and 161/9,568 (1.7\%) patients at 1 year (adjusted odds ratio $0.58,95 \%$ CI 0.47 to $0.71, \mathrm{P}<0.001)$. 
medRxiv preprint doi: https://doi.org/10.1101/2020.09.06.20189308; this version posted September 8, 2020. The copyright holder for this preprint (which was not certified by peer review) is the author/funder, who has granted medRxiv a license to display the preprint in

It is made available under a CC-BY-NC-ND 4.0 International license .

\section{Discussion}

We evaluated the efficacy and safety of implementing an early rule-out pathway in 31,492 consecutive patients with suspected acute coronary syndrome. Introducing the pathway into clinical practice reduced length of stay by 3.3 hours and increased the proportion of patients avoiding hospital admission by $59 \%$. Non-inferiority was not formally demonstrated, but the observed differences in myocardial infarction or cardiac death following discharge favoured the early rule-out pathway.

There are several strengths of our pragmatic trial design. First, we embedded our screening tool into the patient record to ensure we prospectively enrolled consecutive patients whom the attending clinician suspected acute coronary syndrome. This minimised the risk of selection bias, ensuring we did not limit our findings to low-risk patients or those presenting within working hours. Second, as the intervention was implemented at the hospital level, we did not seek individual patient consent. This reduced the risk of a Hawthorne effect where effectiveness is exaggerated through direct observation of clinical care by researchers. Third, our trial population was larger than the combined number of patients enrolled in 30 previous observational studies.26,27 This ensured we had a greater number of events to evaluate safety. Finally, we combined hospital-level data with established registries to ensure follow up was complete in $99.8 \%$ of participants, and that our panel was able to adjudicate all safety outcome events.

The High-STEACS early rule-out pathway determines whether a patient with suspected acute coronary syndrome requires hospital admission or can be safely discharged. It is based on three principles. First, patients with very low troponin concentrations are at low-risk of cardiac events.6 We defined the optimal risk stratification threshold as the highest 
medRxiv preprint doi: https://doi.org/10.1101/2020.09.06.20189308; this version posted September 8, 2020. The copyright holder for this preprint (which was not certified by peer review) is the author/funder, who has granted medRxiv a license to display the preprint in It is made available under a CC-BY-NC-ND 4.0 International license .

concentration that gave a negative predictive value of $>99.5 \%$ for myocardial infarction or cardiac death at 30 days, 8,26 to maximise the effectiveness of this approach whilst maintaining safety. Second, increasing concentrations above this risk stratification threshold on repeat testing may be important, even if they remain within the normal reference range, and these patients require admission to measure peak troponin concentration. $18 \mathrm{We}$ define this using a change in concentration of $\geq 3 \mathrm{ng} / \mathrm{L}$, based on the lowest measurable change that exceeds biological and analytical variation.28 Third, to ensure our pathway is consistent with international guidelines, 4 we applied the sex-specific 99 th centile as the threshold to identify patients who require hospital admission. Adherence was good across all seven acute hospitals which is testament to the simplicity of the pathway and should encourage adoption.

Whilst many pathways have been developed and validated that incorporate separate risk stratification and diagnostic thresholds, 12,29 this is the first time that implementation has been evaluated in a prospective randomised controlled trial of consecutive patients. Here, we report substantial reductions in length of stay and increases in the proportion of patients avoiding hospital admission. Were these gains to be realised across healthcare systems, the benefits for both patients and providers would be substantial. In the US alone, more than 20 million patients with suspected acute coronary syndrome attend Emergency Departments each year.1 A reduction in the length of stay of 3 hours could save more than $\$ 3.6$ billion per annum on bed occupancy alone.30 Despite these important reductions in length of stay, during the implementation phase the median stay was 6.8 hours, which is longer than reported in other evaluations of the implementation of early rule-out pathways.14,15 This difference likely reflects our enrollment of all consecutive patients rather than selected patients who are less likely to have co-morbid conditions requiring hospital admission. 
medRxiv preprint doi: https://doi.org/10.1101/2020.09.06.20189308; this version posted September 8, 2020. The copyright holder for this preprint (which was not certified by peer review) is the author/funder, who has granted medRxiv a license to display the preprint in It is made available under a CC-BY-NC-ND 4.0 International license .

Implementation of our early rule-out pathway did not increase the rate of subsequent myocardial infarction or cardiac death. However, our results were highly sensitive to the model specification. Although non-inferiority was not concluded for the primary safety outcome at 30 days, in our prespecified sensitivity analysis restricted to calendar matched periods, the early rule-out pathway was superior to standard care at 30 days and 1 year. These divergent results may be due to the low event rate at 30 days and narrow randomisation phase leading to overfitting of the primary analysis model, additional secular changes not accounted for in the sensitivity analysis, or a true exposure-time effect whereby outcomes improved as the intervention became more firmly embedded into practice.

Is it plausible that the introduction of an early rule-out pathway could reduce the risk of subsequent cardiac events? By using a threshold well below the $99_{\text {th }}$ centile to risk stratify patients and by recognising that small changes in troponin concentration within the reference range may be important, we may have improved the evaluation of risk compared to using a single higher threshold to rule in and rule out myocardial infarction. This is supported by recent observational studies, which report that using the 99 th centile to rule out myocardial infarction at presentation and at 3 hours, misses 1 in 50 patients who would have been identified on serial testing 6-12 hours following the onset of symptoms.18,31,32 Furthermore, our pathway encourages serial testing to safely rule out myocardial infarction in early presenters, which is now recognised by international guidelines.33,34 More prospective trials in which clinical decisions are guided by new diagnostic approaches are needed to ensure our guidelines are based on the highest quality evidence.

Our findings add to those from a recently published randomised trial, which compared a 1hour and 3-hour rule-out pathway.15 In 3,378 patients the 1-hour pathway reduced length of 
medRxiv preprint doi: https://doi.org/10.1101/2020.09.06.20189308; this version posted September 8, 2020. The copyright holder for this preprint (which was not certified by peer review) is the author/funder, who has granted medRxiv a license to display the preprint in It is made available under a CC-BY-NC-ND 4.0 International license.

stay by 60 minutes and increased discharge rates from $32 \%$ to $45 \%$. The trial concluded noninferiority for an endpoint of all-cause mortality or myocardial infarction within 30 days, although there was an increase in secondary safety outcome events in the 1-hour pathway arm. Due to a perceived lack of equipoise the monitoring committee recommended the trial stop recruitment with just two-thirds of the target population enrolled, and only one patient had a type 1 myocardial infarction following discharge in each arm.

We acknowledge several potential study limitations. Whilst the early rule-out pathway was implemented across three steps in the randomisation phase, we had to accept flexibility in the date of implementation (Supplement). This limited our ability to interpret a planned sensitivity analysis within the randomisation phase, when there were sites using both the standard care and early rule-out pathway. Additionally, we enrolled fewer than the 38,994 patients anticipated in our sample size calculations, and identified fewer safety outcome events at 30 days. We believe this in part contributed to modelling issues when attempting to evaluate the safety outcome at 30 days. However, more than 700 patients had a myocardial infarction or cardiac death at 1 year, and the rates of all secondary outcome measures were lower following implementation of the early rule-out pathway. Our pathway has been validated for use with two troponin I assays and a troponin T assay,17,18,35 and whilst it is likely to perform similarly for all high-sensitivity assays, further research is required to confirm this.

In conclusion, implementation of an early rule-out pathway for myocardial infarction substantially reduced length of stay and increased the proportion of patients avoiding hospital admission with no increase in adverse cardiac events. Adoption of this approach would have major benefits for both patients and healthcare providers. 
medRxiv preprint doi: https://doi.org/10.1101/2020.09.06.20189308; this version posted September 8, 2020. The copyright holder for this preprint (which was not certified by peer review) is the author/funder, who has granted medRxiv a license to display the preprint in

It is made available under a CC-BY-NC-ND 4.0 International license .

\section{Author Contribution and Transparency Statement}

The HiSTORIC Investigators contributed to the conception or design of the work, or the acquisition, analysis, or interpretation of data for the work. They were involved in drafting the manuscript and revising it, and have given final approval of the version to be published. The study sponsor had no role in the study design, collection of data, analysis and interpretation of data, writing of this report or decision to submit for publication. The corresponding author affirms that the manuscript is an honest, accurate, and transparent account of the study being reported and that no important aspects of the study have been omitted.

\section{Declarations of Interest}

AA, ARC, ASVS have received honoraria from Abbott Diagnostics. CB reports research grants awarded to the University of Glasgow from Abbott Vascular, AstraZeneca, Boehringer Ingelheim, GSK, HeartFlow, Novartis and Siemens Healthcare outside the submitted work. FSA reports research grants awarded to the Minneapolis Medical Research Foundation from Abbott Diagnostics, Siemens Diagnostics, Ortho-Clinical Diagnostics, and Beckman Coulter outside the submitted work, and personal fees from HyTest Ltd. NLM reports research grants awarded to the University of Edinburgh from Abbott Diagnostics and Siemens Healthineers outside the submitted work, and honoraria from Abbott Diagnostics, Siemens Healthineers, Roche Diagnostics and Singulex. All other authors have no interests to declare.

\section{Data Sharing}

The HiSTORIC trial makes use of multiple routine electronic health care data sources that are linked, deidentified and held in our national safe haven, which is accessible by approved 
medRxiv preprint doi: https://doi.org/10.1101/2020.09.06.20189308; this version posted September 8, 2020. The copyright holder for this preprint (which was not certified by peer review) is the author/funder, who has granted medRxiv a license to display the preprint in

It is made available under a CC-BY-NC-ND 4.0 International license .

individuals who have undertaken the necessary governance training. Summary data can be made available upon request to the corresponding author.

\section{Acknowledgements}

This trial was funded by the British Heart Foundation (BHF) (PG/15/51/31596) with support from BHF Research Excellence Awards (RE/18/5/34216; RE/18/6134217). AA, KL and ARC are supported by a Clinical Lectureship from the Chief Scientist Office (PCL/18/05), a Clinical Research Training Fellowship from the BHF (FS/18/25/33454), and a Clinical Lectureship from the Scottish Clinical Research Excellence Development Scheme, respectively. DEN, ASVS, and NLM are supported by the BHF through the award of a Chair (CH/09/002), an Intermediate Clinical Research Fellowship (FS/19/17/34172), and the Butler Senior Clinical Research Fellowship (FS/16/14/32023), respectively. PDA is supported by a National Heart Foundation of New Zealand Senior Fellowship (1844). DEN is a recipient of a Wellcome Trust Senior Investigator Award (WT103782AIA). CJW and RP were supported by NHS Lothian through the Edinburgh Clinical Trials Unit. The funders played no role in the design, conduct, data collection, analysis or reporting of the trial. We would like to thank researchers from the Emergency Medicine Research Group Edinburgh and the Edinburgh Clinical Trials Unit for their support during the conduct of this trial. 
medRxiv preprint doi: https://doi.org/10.1101/2020.09.06.20189308; this version posted September 8, 2020. The copyright holder for this preprint (which was not certified by peer review) is the author/funder, who has granted medRxiv a license to display the preprint in It is made available under a CC-BY-NC-ND 4.0 International license .

\section{References}

1. Hollander JE, Than M, Mueller C. State-of-the-art evaluation of emergency department patients presenting with potential acute coronary syndromes. Circulation 2016; 134 : $547-564$.

2. Goodacre S, Cross E, Arnold J, Angelini K, Capewell S, Nicholl J. The health care burden of acute chest pain. Heart 2005; 91: 229-230.

3. Anderson JL, Morrow DA. Acute myocardial infarction. N Engl J Med 2017; 376: 2053-2064

4. Thygesen K, Alpert JS, Jaffe AS, Simoons ML, Chaitman BR, White HD, et al. Third universal definition of myocardial infarction. Circulation 2012; 126: 2020-35.

5. Apple FS, Collinson PO. Analytical characteristics of high-sensitivity cardiac troponin assays. Clin Chem 2012; 58: 54-61.

6. Body R, Carley S, McDowell G, Jaffe AS, France M, Cruickshank K, et al. Rapid exclusion of acute myocardial infarction in patients with undetectable troponin using a high-sensitivity assay. J Am Coll Cardiol 2011; 58: 1332-1339.

7. Body R, Mueller C, Giannitsis E, Christ M, Ordonez-Llanos J, de Filippi CR, et al on behalf of the TRAPID-AMI Investigators. The use of very low concentrations of highsensitivity troponin $\mathrm{T}$ to rule out acute myocardial infarction using a single blood test. Acad Emerg Med 2016; 23: 1004-1013.

8. Shah ASV, Anand A, Sandoval Y, Lee KK, Smith SW, Adamson PD, et al. on behalf of the High-STEACS Investigators. High-sensitivity cardiac troponin I at presentation in patients with suspected acute coronary syndrome. Lancet 2015; 386: 2481-2488.

9. Boeddinghaus J, Nestelberger T, Twerenbold R, Wildi K, Badertscher P, Cupa J, 
medRxiv preprint doi: https://doi.org/10.1101/2020.09.06.20189308; this version posted September 8, 2020. The copyright holder for this preprint (which was not certified by peer review) is the author/funder, who has granted medRxiv a license to display the preprint in It is made available under a CC-BY-NC-ND 4.0 International license .

et al. Direct comparison of 4 very early rule-out strategies for acute myocardial infarction using high-sensitivity cardiac troponin I. Circulation 2017; 135: 1597-1611.

10. Sandoval Y, Smith SW, Love SA, Sexter A, Schulz K, Apple FS. Single highsensitivity cardiac troponin I to rule out acute myocardial infarction. Am J Med 2017; 130: 1076-1083.

11. Lindahl B, Jernberg T, Badertscher P, Boeddinghaus J, Eggers KM, Frick M, et al. An algorithm for rule-in and rule-out of acute myocardial infarction using a novel troponin I assay. Heart 2017; 103: 125-131.

12. Neumann JT, Twerenbold R, Ojeda F, Sörensen NA, Chapman AR, Shah ASV, et al. Application of high-sensitivity troponin in suspected myocardial infarction. $N$ Engl J Med 2019; 380: 2529-2540.

13. Greenslade J, Cho E, Van Hise C, Hawkins T, Parsonage W, Ungerer J, et al. Evaluating rapid rule-out of acute myocardial infarction using a high-sensitivity cardiac troponin I assay at presentation. Clin Chem 2018; 64: 820-829.

14. Twerenbold R, Costabel JP, Nestelberger T, Campos R, Wussler D, Arbucci R, et al. Outcome of Applying the ESC 0/1-hour Algorithm in Patients With Suspected Myocardial Infarction. J Am Coll Cardiol 2019; 74: 483-494.

15. Chew DP, Lambrakis K, Blyth A, Seshadri A, Edmonds MJR, Briffa T et al. A Randomised Trial of a 1-Hour Troponin T Protocol in Suspected Acute Coronary Syndromes: The Rapid Assessment of Possible ACS In the Emergency Department with High Sensitivity Troponin T (RAPID-TnT) Study. Circulation 2019; 140: 15431556.

16. Shah ASV, Anand A, Strachan FE, Ferry AV, Lee KK, Chapman AR, et al. on behalf of the High-STEACS Investigators. High-sensitivity troponin in the evaluation of 
medRxiv preprint doi: https://doi.org/10.1101/2020.09.06.20189308; this version posted September 8, 2020. The copyright holder for this preprint (which was not certified by peer review) is the author/funder, who has granted medRxiv a license to display the preprint in It is made available under a CC-BY-NC-ND 4.0 International license .

patients with suspected acute coronary syndrome: a stepped-wedge, cluster-randomised controlled trial. Lancet 2018; 392: 919-928.

17. Scottish Intercollegiate Guidelines Network (SIGN). Acute coronary syndromes. Edinburgh: SIGN; 2103. (SIGN publication no. 93). [February 2013]

18. Chapman AR, Anand A, Boeddinghaus J, Ferry AV, Sandeman D, Adamson PD, et al. Comparison of the efficacy and safety of early rule-out pathways for acute myocardial infarction. Circulation 2017; 135: 1586-1596.

19. Chapman AR, Fujisawa T, Lee KK, Andrews JP, Anand A, Sandeman D, et al. Novel high-sensitivity cardiac troponin I assay in patients with suspected acute coronary syndrome. Heart 2019; 105: 616-622.

20. Chin CL, Shah ASV, McAllister DA, Cowell JS, Alam S, Langrish JP, et al. Highsensitivity troponin I concentrations are a marker of an advanced hypertrophic response and adverse outcomes in patients with aortic stenosis. Eur Heart J. 2014; 35: 23122321.

21. Shah ASV, Griffiths M, Lee KK, McAllister DA, Hunter AL, Ferry AV, et al. High sensitivity cardiac troponin and the under-diagnosis of myocardial infarction in women: prospective cohort study. $B M J$ 2015; 350: g7873.

22. The SCOT-HEART investigators. CT coronary angiography in patients with suspected angina due to coronary heart disease (SCOT-HEART): an open-label, parallel-group, multicentre trial. Lancet 2015; 385: 2383-2391.

23. NHS National Services Scotland: Information Services Division (ISD). Scottish heart disease statistics. A National Statistics Publication for Scotland, 30th Jan 2018; 1-52.

24. Shah ASV, Sandoval Y, Noaman A, Sexter A, Vaswani A, Smith SW, at al. Patient selection for high sensitivity cardiac troponin testing and diagnosis of myocardial infarction: prospective cohort study. BMJ 2017;359: j4788. 
medRxiv preprint doi: https://doi.org/10.1101/2020.09.06.20189308; this version posted September 8, 2020. The copyright holder for this preprint (which was not certified by peer review) is the author/funder, who has granted medRxiv a license to display the preprint in It is made available under a CC-BY-NC-ND 4.0 International license .

25. Thygesen K, Alpert JS, Jaffe AS, Chaitman BR, Bax JJ, Morrow DA, et al. on behalf of the Joint European Society of Cardiology (ESC)/American College of Cardiology (ACC)/American Heart Association (AHA)/World Heart Federation (WHF) Task Force for the Universal Definition of Myocardial Infarction. Fourth Universal Definition of Myocardial Infarction. Circulation. 2018; 138: e618-e651.

26. Chapman AR, Lee KK, McAllister DA, Cullen L, Greenslade JH, Parsonage W, et al. Association of high-sensitivity cardiac troponin I concentration with cardiac outcomes in patients with suspected acute coronary syndrome. JAMA 2017; 318: 1913-1924.

27. Pickering JW, Than MP, Cullen L, Aldous S, Ter Avest E, Body R, et al. Rapid ruleout of acute myocardial infarction with a single high-sensitivity cardiac troponin $\mathrm{T}$ measurement below the limit of detection: A collaborative meta-analysis. Ann Intern Med 2017; 166: 715-724.

28. Kavsak PA, Don-Wauchope AC, Hill SA, Worster A. Acceptable analytical variation may exceed high-sensitivity cardiac troponin I cutoffs in early rule-out and rule-in acute myocardial infarction algorithms. Clin Chem 2016; 62: 887-889.

29. Reichlin T, Schindler C, Drexler B, Twerenbold R, Reiter M, Zellweger C, et al. Onehour rule-out and rule-in of acute myocardial infarction using high-sensitivity cardiac troponin T. Arch Intern Med. 2012; 172: 1211-1218.

30. Probst MA, McConnell JK, Weiss RE, Laurie AL, Yagapen AN, Lin MP, et al. Estimating the Cost of Care for Emergency Department Syncope Patients: Comparison of Three Models. West J Emerg Med 2017; 18: 253-257.

31. Pickering JW, Greenslade JH, Cullen L, Flaws D, Parsonage W, George P, et al. Validation of presentation and $3 \mathrm{~h}$ high-sensitivity troponin to rule-in and rule-out acute myocardial infarction Heart 2016; 102: 1270-1278. 
medRxiv preprint doi: https://doi.org/10.1101/2020.09.06.20189308; this version posted September 8, 2020. The copyright holder for this preprint (which was not certified by peer review) is the author/funder, who has granted medRxiv a license to display the preprint in It is made available under a CC-BY-NC-ND 4.0 International license .

32. Parsonage WA, Mueller C, Greenslade JH, Wildi K, Pickering J, Than M, et al. Validation of NICE diagnostic guidance for rule out of myocardial infarction using high-sensitivity troponin tests. Heart 2016; 102: 1279-1286.

33. Roffi M, Patrono C, Collet JP, Mueller C, Valgimigli M, Andreotti F, et al. 2015 ESC Guidelines for the management of acute coronary syndromes in patients presenting without persistent st-segment elevation: Task force for the management of acute coronary syndromes in patients presenting without persistent ST-segment elevation of the European Society of Cardiology (ESC). Eur Heart J 2016; 37: 267-315.

34. Amsterdam EA, Wenger NK, Brindis RG, Casey DE Jr, Ganiats TG, Holmes DR Jr, et $a l$. on behalf of ACC/AHA Task Force Members, Society for Cardiovascular Angiography and Interventions and the Society of Thoracic Surgeons. 2014 AHA/ACC guideline for the management of patients with non-ST-elevation acute coronary syndromes: executive summary: a report of the American College of Cardiology/American Heart Association Task Force on Practice Guidelines. Circulation 2014; 130: 2354-2394.

35. Chapman AR, Sandeman D, Ferry AV, Stewart S, Strachan FE, Wereski R, Bularga A, Anand A, Shah ASV, Mills NL. Risk Stratification Using High-Sensitivity Cardiac Troponin T in Patients With Suspected Acute Coronary Syndrome. J Am Coll Cardiol. 2020 Mar 3;75(8):985-987. 
medRxiv preprint doi: https://doi.org/10.1101/2020.09.06.20189308; this version posted September 8,2020 . The copyright holder for this

preprint (which was not certified by peer review) is the author/funder, who has granted medRxiv a license to display the preprint in

It is made available under a CC-BY-NC-ND 4.0 International license

\section{Figure Legends}

Figure 1. Schematic diagram of the HiSTORIC trial design and the early-rule out pathway

a) During a validation phase of at least 6 months, cardiac troponin testing was performed at presentation and was repeated 6 or 12 hours after the onset of symptoms with myocardial infarction ruled out where cardiac troponin concentrations were less than the sex-specific 99 th centile (standard care). Sites were paired based on the expected number of patients and randomised to implement the early rule out pathway pathway (intervention) in one of three steps during a 6 month randomisation phase. Finally, all sites completed an implementation phase of at least 6 months that was calendar matched to the validation phase where patient care was guided by the early rule-out pathway.

b) The early rule-out pathway rules out myocardial infarction at presentation in patients with cardiac troponin concentrations below a risk stratification threshold of $5 \mathrm{ng} / \mathrm{L}$, unless they presented within 2 hours of symptom onset where testing is repeated 3 hours from presentation. Patients with cardiac troponin concentrations $\geq 5 \mathrm{ng} / \mathrm{L}$ at presentation are retested in the Emergency Department 3 hours after presentation, and myocardial infarction is ruled out if concentrations are unchanged (delta $<3 \mathrm{ng} / \mathrm{L}$ ) and remain below the $99_{\text {th }}$ centile diagnostic threshold. 
medRxiv preprint doi: https://doi.org/10.1101/2020.09.06.20189308; this version posted September 8, 2020. The copyright holder for this preprint (which was not certified by peer review) is the author/funder, who has granted medRxiv a license to display the preprint in It is made available under a CC-BY-NC-ND 4.0 International license

Figure 2. Length of stay before and after implementation of the early rule-out pathway

Shown is a density plot of the length of stay in patients evaluated before (blue) and after (red) implementation of the early rule-out pathway.

Figure 3. Myocardial infarction or cardiac death following discharge before and after implementation of the early rule-out pathway

Shown are cumulative incidence time-to-event curves for the primary safety outcome of myocardial infarction or cardiac death for patients evaluated before (blue line) and after (red line) implementation of the early rule-out pathway. 
medRxiv preprint doi: https://doi.org/10.1101/2020.09.06.20189308; this version posted September 8, 2020. The copyright holder for this preprint (which was not certified by peer review) is the author/funder, who has granted medRxiv a license to display the preprint in perpetuity.

It is made available under a CC-BY-NC-ND 4.0 International license .

Table 1. Characteristics of the Trial Participants

\begin{tabular}{|c|c|c|c|}
\hline & All & Standard care & Early rule-out \\
\hline No. of participants & 31,492 & 14,700 & 16,792 \\
\hline Age (years) & $59 \pm 17$ & $59 \pm 17$ & $58 \pm 17$ \\
\hline Women & $14,252(45)$ & $6,575(45)$ & $7,677(46)$ \\
\hline \multicolumn{4}{|l|}{ Presenting complaint } \\
\hline Chest pain & $26,590(84)$ & $12,566(85)$ & $14,024(84)$ \\
\hline Dyspnoea & $957(3)$ & $420(3)$ & $537(3)$ \\
\hline Palpitation & $928(3)$ & $432(3)$ & $496(3)$ \\
\hline Syncope & $1,701(5)$ & $699(5)$ & $1,002(6)$ \\
\hline Other & $1,316(4)$ & $583(4)$ & $733(4)$ \\
\hline \multicolumn{4}{|l|}{ Past medical history } \\
\hline Myocardial infarction & $2,573(8)$ & $1,371(9)$ & $1,202(7)$ \\
\hline Ischaemic heart disease & $7,346(23)$ & $3,834(26)$ & $3,512(21)$ \\
\hline Cerebrovascular disease & $1,684(5)$ & $849(6)$ & $835(5)$ \\
\hline Diabetes mellitus & $1,912(6)$ & $1,002(7)$ & $910(5)$ \\
\hline \multicolumn{4}{|l|}{ Previous revascularisation } \\
\hline PCI & $2,831(9)$ & $1,534(10)$ & $1,297(8)$ \\
\hline CABG & $452(1)$ & $240(2)$ & $212(1)$ \\
\hline \multicolumn{4}{|l|}{ Medications at presentation } \\
\hline Aspirin & $8,023(25)$ & $4,114(28)$ & $3,909(23)$ \\
\hline Dual anti-platelet therapy* & $1,269(4)$ & $738(5)$ & $531(3)$ \\
\hline Statin & $12,165(39)$ & $6,035(41)$ & $6,130(37)$ \\
\hline ACE inhibitor or ARB & $9,769(31)$ & $4,776(32)$ & $4,993(30)$ \\
\hline Beta-blocker & $8,548(27)$ & $4,162(28)$ & $4,386(26)$ \\
\hline Oral anti-coagulant $\dagger$ & $2,167(7)$ & $1,033(7)$ & $1,134(7)$ \\
\hline \multicolumn{4}{|l|}{ Electrocardiogram $\ddagger$} \\
\hline Normal & $12,035(74)$ & $6,118(73)$ & $5,917(75)$ \\
\hline Myocardial ischemia & $3,288(20)$ & $1,756(21)$ & $1,532(20)$ \\
\hline ST-segment elevation & $193(1)$ & $111(1)$ & $82(1)$ \\
\hline ST-segment depression & $252(2)$ & $146(2)$ & $106(1)$ \\
\hline $\mathrm{T}$-wave inversion & $1,225(8)$ & $621(7)$ & $604(8)$ \\
\hline Other & $1,711(11)$ & $927(11)$ & $784(10)$ \\
\hline \multicolumn{4}{|l|}{ Haematology and clinical chemistry } \\
\hline Haemoglobin, g/L & $137 \pm 22$ & $137 \pm 20$ & $137 \pm 23$ \\
\hline $\mathrm{eGFR}, \mathrm{mL} / \mathrm{min}$ & $81 \pm 22$ & $81 \pm 23$ & $82 \pm 22$ \\
\hline Presentation hs-cTnI, ng/L & $3[1-6]$ & $3[1-6]$ & $3[1-6]$ \\
\hline Peak hs-cTnI, ng/L & $3[1-7]$ & $3[1-7]$ & $3[1-7]$ \\
\hline Serial $(\geq 2)$ tests $\S$ & $11,904(38)$ & $6,540(44)$ & $5,364(32)$ \\
\hline \multicolumn{4}{|l|}{ Time intervals } \\
\hline Symptom onset to presentation $\leq 2 \mathrm{hrs}$ & $5,664(18)$ & 2,859 (19) & $2,805(17)$ \\
\hline Presentation to first test, mins & 66 [45-97] & 66 [46-97] & 65 [43-97] \\
\hline First to second test, mins & $351[188-553]$ & $455[267-601]$ & $229[155-405]$ \\
\hline
\end{tabular}

Presented as No. (\%), mean \pm SD or median [inter-quartile range]. Abbreviations: $\mathrm{ACE}=$ angiotensin converting enzyme; $\mathrm{ARB}=$ angiotensin receptor blockers; eGFR $=$ estimated glomerular filtration rate; $\mathrm{CABG}=$ coronary artery bypass grafting; $\mathrm{PCI}=$ percutaneous coronary intervention .

* Two medications from aspirin, clopidogrel, prasugrel or ticagrelor. $\dagger$ Includes warfarin or novel oral anti-coagulants. $\$$ Proportions reported for the $16,217(51 \%)$ participants with electrocardiographic data available. $§$ Serial testing was defined as two or more tests within 24 hours of presentation. 
Table 2. Efficacy and Safety Outcomes at 30 Days and 1 Year

\begin{tabular}{|c|c|c|c|c|c|}
\hline & All & Standard care & Early rule-out & Adjusted Odds Ratio (95\% CI)* & P-value \\
\hline No. of participants & $n=31,492$ & $\mathrm{n}=14,700$ & $\mathrm{n}=16,792$ & & \\
\hline \multicolumn{6}{|l|}{ Efficacy outcome } \\
\hline Length of stay, hrs (primary) & $8.2 \pm 4.1$ & $10.1 \pm 4.1$ & $6.8 \pm 4.1$ & 0.78 (95\% CI 0.73 to 0.83$)$ & $\mathrm{P}<0.001$ \\
\hline Discharge from the ED (secondary) & $19,249(61)$ & $7,407(50)$ & $11,842(71)$ & $1.59(95 \%$ CI 1.45 to 1.75$)$ & $\mathrm{P}<0.001$ \\
\hline \multicolumn{6}{|l|}{ Safety outcome $\dagger$} \\
\hline 30 days (primary) & $113(0.4)$ & $57(0.4)$ & $56(0.3)$ & $1.97(95 \%$ CI 0.95 to 4.08$)$ & $\mathrm{P}=0.068$ \\
\hline 1 year (secondary) & $703(2.2)$ & $396(2.7)$ & $307(1.8)$ & $1.02(95 \%$ CI 0.74 to 1.40$)$ & $\mathrm{P}=0.894$ \\
\hline \multicolumn{6}{|l|}{ Other safety outcomes at 1 year } \\
\hline Myocardial infarction $\ddagger$ & $422(1.3)$ & $238(1.6)$ & $184(1.1)$ & $1.10(95 \% \mathrm{CI} 0.72$ to 1.68$)$ & $\mathrm{P}=0.646$ \\
\hline Cardiac death & $319(1.0)$ & $176(1.2)$ & $143(0.9)$ & 1.07 (95\% CI 0.69 to 1.64$)$ & $\mathrm{P}=0.771$ \\
\hline Cardiovascular death & $452(1.4)$ & $249(1.7)$ & $203(1.2)$ & 0.93 (95\% CI 0.66 to 1.32$)$ & $\mathrm{P}=0.696$ \\
\hline All-cause death & $1,720(5.5)$ & $852(5.8)$ & $868(5.2)$ & $0.92(95 \%$ CI 0.75 to 1.12$)$ & $\mathrm{P}=0.385$ \\
\hline Unplanned revascularisation $\S$ & $222(0.7)$ & $119(0.8)$ & $103(0.6)$ & 0.60 (95\% CI 0.35 to 1.03$)$ & $\mathrm{P}=0.065$ \\
\hline Any hospital reattendance & $12,306(39.1)$ & $5,770(39.3)$ & $6,536(38.9)$ & 0.93 (95\% CI 0.84 to 1.02$)$ & $\mathrm{P}=0.112$ \\
\hline
\end{tabular}

Presented as geometric mean \pm standard deviation or No. $(\%)$. Abbreviations: CI = confidence interval, ED = Emergency Department

* Outcomes following implementation of the early rule-out pathway are compared to those during standard care for all measures.

$\uparrow$ Type 1 , type $4 \mathrm{~b}$ or type $4 \mathrm{c}$ myocardial infarction or cardiac death following discharge.

+ Type 1 , type $4 \mathrm{~b}$ or type $4 \mathrm{c}$ myocardial infarction

$\S$ Unplanned revascularisation was defined as urgent or emergency percutaneous coronary intervention or coronary artery bypass grafting from discharge to 1 year 
Figure 1.

a)

Validation phase

\begin{tabular}{r|c|c}
$\begin{array}{c}\text { All sites } \\
(n=7)\end{array}$ & $\begin{array}{c}\text { Standard care } \\
\text { pathway }\end{array}$ & Early rule-out \\
pathway
\end{tabular}

Implementation phase $\quad$ Follow up

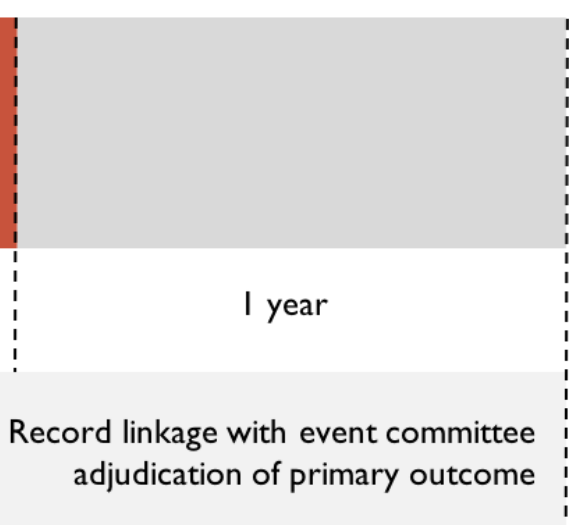




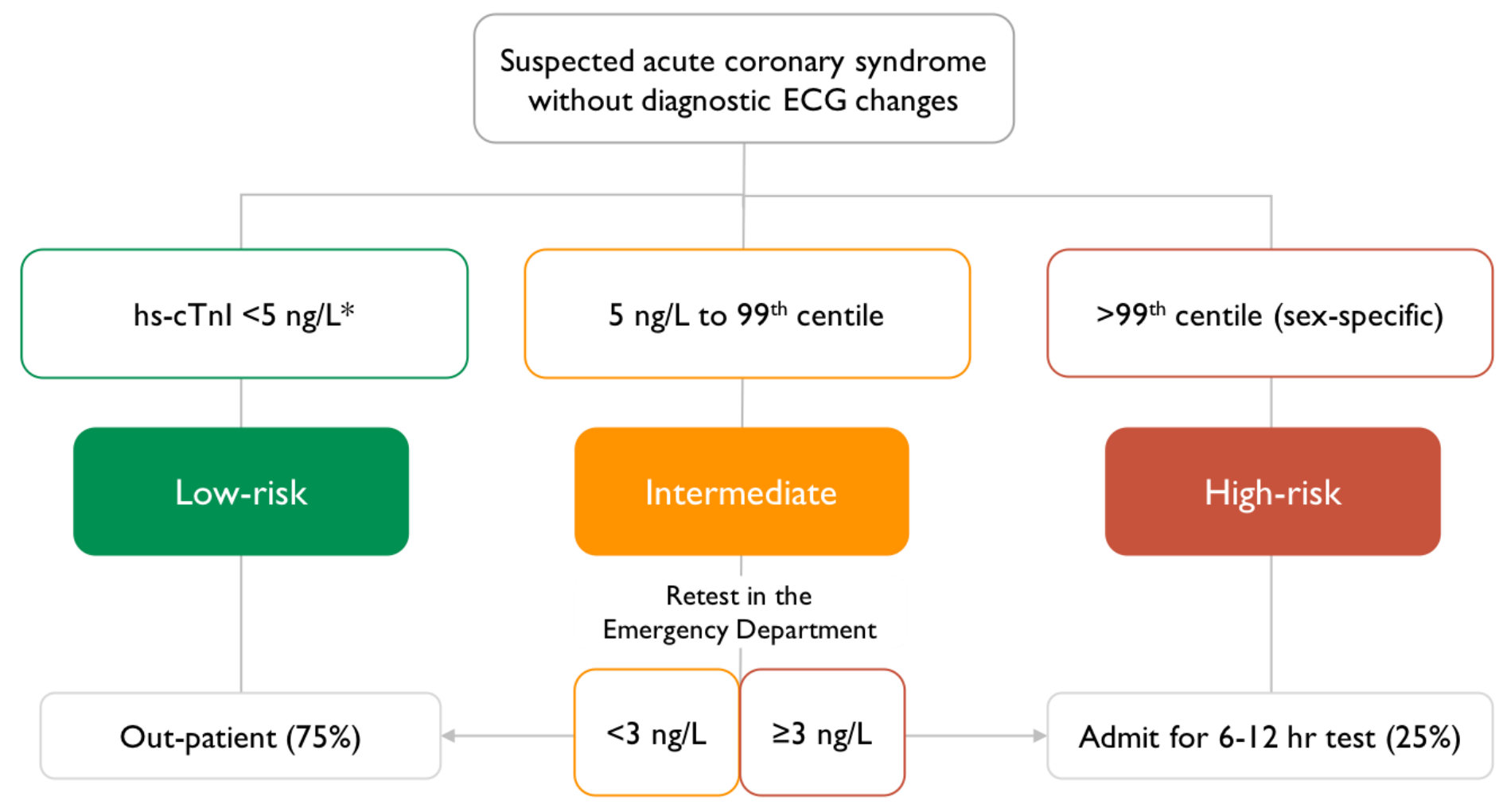

$*$ Retest at $3 \mathrm{~h}$ if $\leq 2 \mathrm{~h}$ from onset 


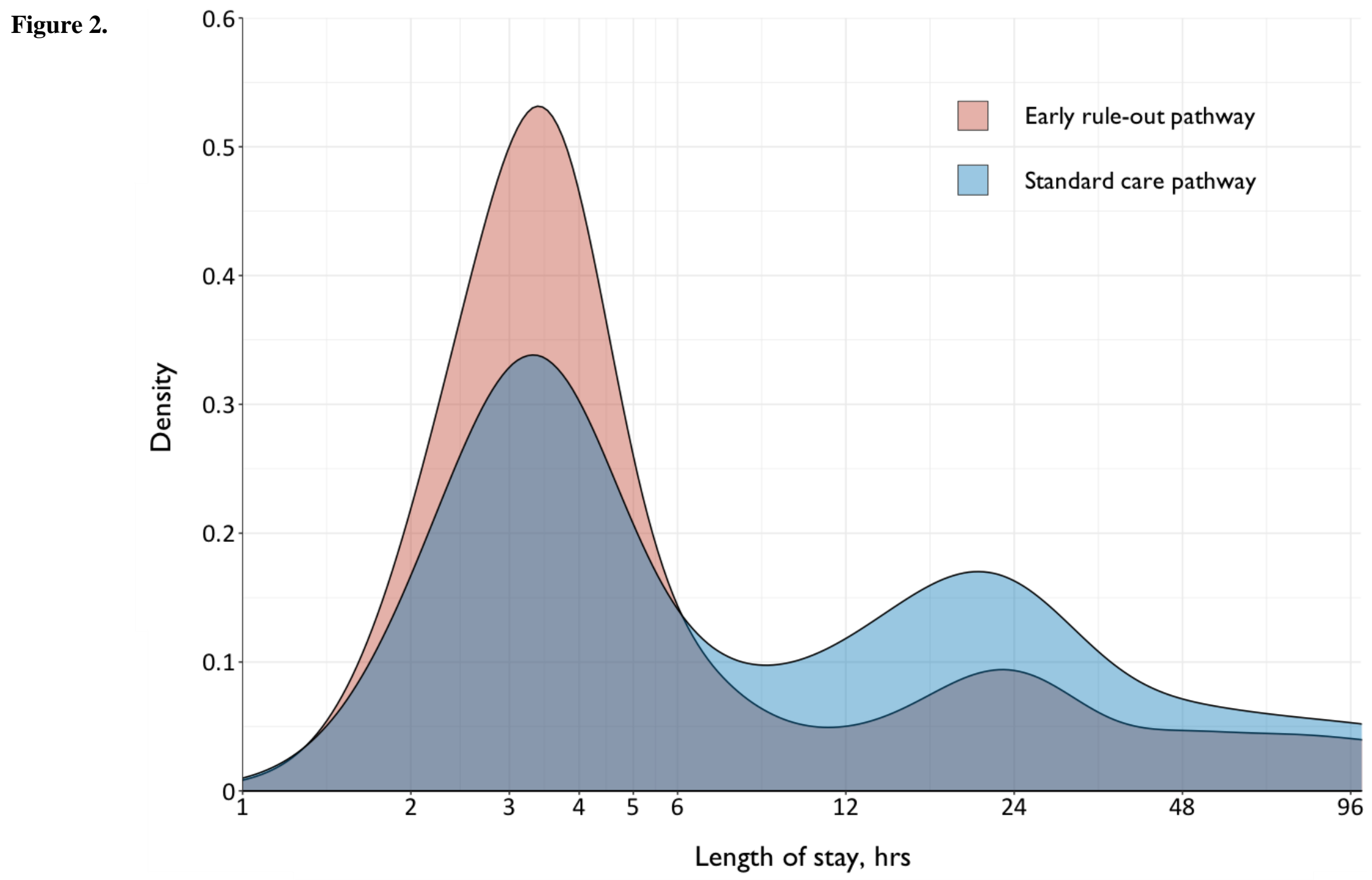


Figure 3.

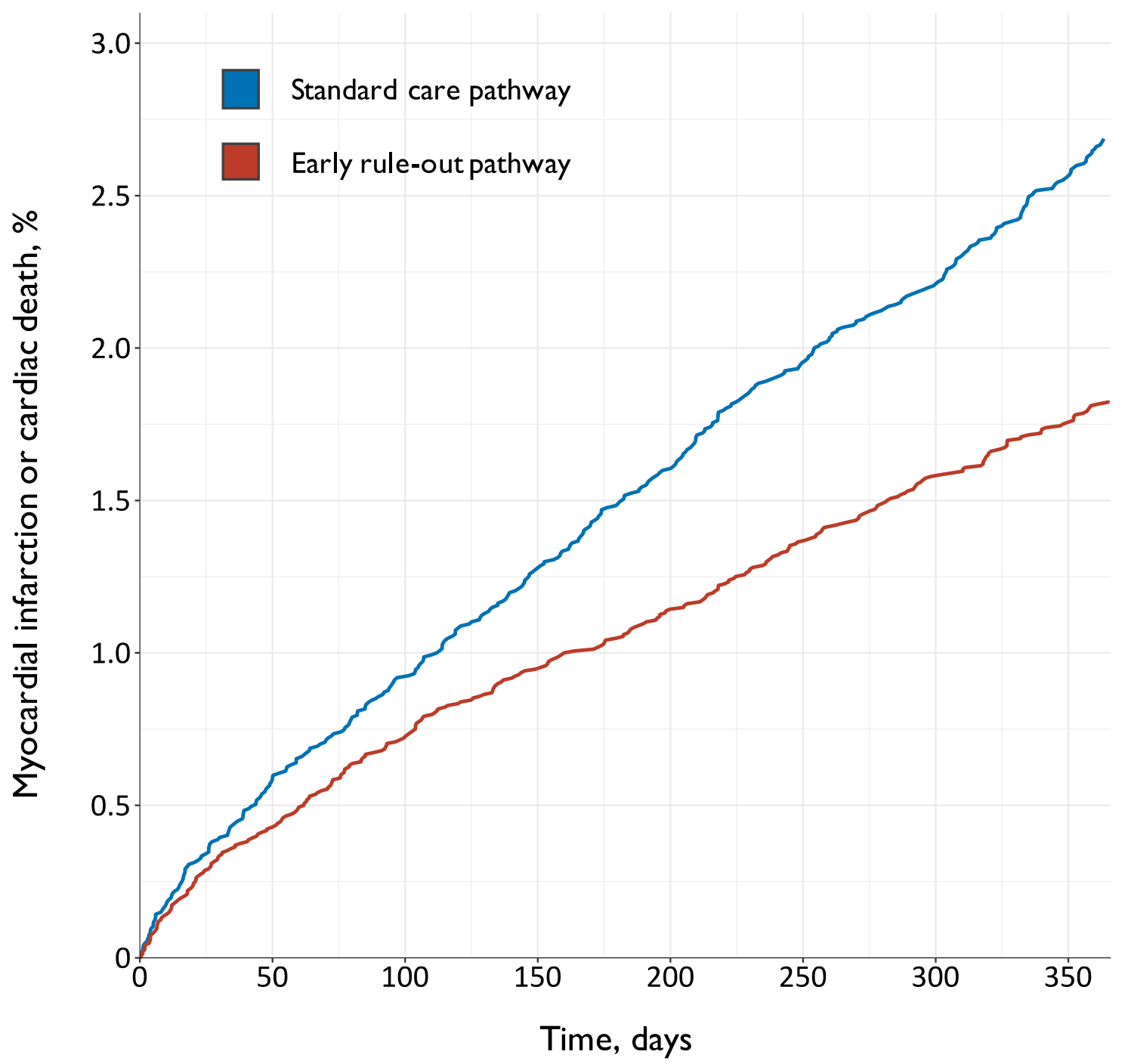

